\title{
Besserwisser za katedrą, czyli o funkcjach prowokacji w poetyce felietonu
}

Joanna Szydłowska 


\section{Joanna Szydłowska}

\section{Besserwisser za katedrą, czyli o funkcjach prowokacji w poetyce felietonu}

$\mathrm{T}$

eza o prowokacyjnym ex definitione clarakterze tekstów felietonowych jest oczywiście daleka od oryginalności. W tym miejscu skoncentrujemy się na wyeksplikowaniu potencjalnych funkcji poetyki prowokacji w tekstach felietonowych. Materiatem analitycznym będą felictony spólki autorskiej: Witold Bereś - Jerzy Skoczylas, publikowane w większości wprzódy w periodykach („Press”, ..Gazeta Wyborcza”), a następnie zebrane w tomie Dziennikarz doskonaty'.

Witold Bereś i Jerzy Skoczylas to dziennikarze o wieloletnim już stażu, mający za sobą współpracę nie tylko z różnymi czasopismami, ale i z radiem² filmem, będący autorami (lub współautorami, tak pospołu, jak i osobno) kilku książek ${ }^{3}$. Możua więc sądzić, że owa praktyka dziennikarska predestynuje ich do podjęcia tematyki obecnej w Dziennikarzu doskonatym. O tym, że nie jest to przedsięwzięcie precedensowe, niech świadczy fakt, że historia przedmiotu zanotowała prawdziwą obfitość książek o mediach kreślonych ręką dziennikarzy whaśnie, by przywołać tylko: instruktażowe tomy Wańkowiczowskiej Karafki La Fontaine'a,

\footnotetext{
'W. Bereś.J. Skoczylas. Dziennikarz doskonaty' w'st. J. Bralczyk. rys. A. Zarçba. Kraków 2000). Oprócz tekstów publikowanych w miesięczniku .,Press" w latach 1997-1999 i jednego zaledwic opublikowanego na lannach ..Gazcty Wyborczej". w wyborze znalazly siç także pierwodruki.

2 Obaj wspólpracowali z RMF FM, a z sckcją polską BBC związał siç swojego czasu Jerzy Skoczylas.

"Autorzy szczególnie cenili sobic gatunck wywiadu. Taką proweniencję gatunkową mają miçdzy innymi: G'nerat Kiszczak món' prau'e w'szystko, rozm. przepr. W. Bereś.J. Skoczylas. Warszawa 1991: Gliniarz z "Tiguodnika", rozm. przepr. W. Bereś. K. Burnetko. Warszawa 1991 I. Skoczylas byl równicż ghost-m riterem skandalizu-

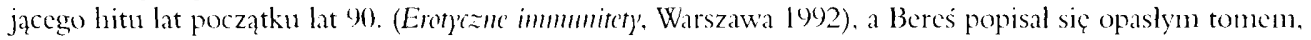
w którym wyselekcjonowal i opatrzyl komentarzenn najistotnicjsze wydarzenia medialne ostatniego dzicsię-

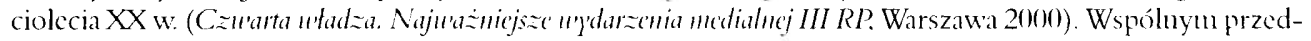
sięwzięciem autorów jest równicz wybór satyrycznych felictonów puświçconych polskicj scenic polityczncj D):ma 2000, Warszawa 2000.
} 
catkiem nowe, ale juz na trwałe wpisane do kanonu lektur obowiązkowych Lapidaria Ryszarda Kapuścińskiego i całą mnogość tytułów o charakterze warsztatowym (ostatnimi czasy między innymi Jerzego Niczyperowicza, Andrzeja Magdonia, Stanisława Bortnowskiego) bądź wspomnieniowym ${ }^{4}$.

Oto jednak swą „dydaktykę medialną” Bereś i Skoczylas ubierają w kostium felietonu gatunku o nader wąttej stabilności, w którym nieprawomocność wszelkich uogólnień wspólistnieje z manifestacyjną antyistytucjonalnością i programową niekonkluzywnością merytoryczı $a^{5}$. Ale i w tym wypadku interesująca nas spólka autorska nie pokusiła się o precedens. Autotematyczny charakter miał wszak juz O felietonie felieton Cypriana Kamila Norwida, publikowany na lamach „Gonica Polskiego” w 1851 roku, a jednym z ostatnio opublikowanych zbiorów felietonów poświęconych realiom wspólczesnego polskiego dziennikarstwa jest Iádemecum redaktora Mariusza Ziomeckiego".

Można przyjąć, że w interesującym nas zbiorze poetyka prowokacji funkcjonuje na kilku poziomach. Są to: sfera tytularna, wybór konwencji przekazu, konstytucja podmiotu narracji, plaszczyzna merytoryczna i warstwa stylistyczno-leksykalna. Te właśnie struktury będą przedmiotem naszego oglądu.

Zbiór felie tonów, jeśli ich nie pisał Prus lub Slonimski, przeważnie sluży autorowi jako sposób na powtórną utylizację raz już sprzedanych tekstów ${ }^{7}$ -

— pisał nieco zgryźliwie Ennest Skalski. I zapewne miał rację. Ale niegdysiejszy zastępca redaktora naczelnego, a następnie komentator „Gazety Wyborczej” przeoczył istotny fakt zmiany statusu tekstu prasowego wraz z zaistnieniem go w materii publikacji zwartej. Tak jest nie tylko z felietonem, ale i reportażem, którego antologie (także retrospektywne) niezmiennie cieszą się popularnością wśród odbiorców. I nie chodzi tu wyłącznie o „przedlużoną aktualność", której dopatrywal się w wybranych tekstach reportażowych Zbigniew Stolarek ${ }^{\gamma}$. Wydane w oddzielnym zbiorze teksty prasowe wyzbywają się cechy ulotności komunikatu prasowego, w recepcji czytelniczej uwolnione zostają od kontekstu neu'sa, nade wszystko - łacniej ukazują swą spójność: choćby tematyczną czy stylistyczną.

Przyjrzyjmy się tej transformacji na przykladzie tekstów Beresia i Skoczylasa. Wydane w publikacji zwartej materialy zdają się realizować konwencję poważnego kompendium, cc

+Zob. mięc dzy innymi serię Asy' polskiego dzicmnikarstu'a, któną zainaugurowala książa Zau'ód reporter: Ambrozic u'icz, Warszawa 2000.

"Por. przegląd definicji gatunku: P. Stasiński. Poctyka i pragmatyka felictonu, Wroclaw 1982; A. Ropa, W' poszuki "duriu istoty felictomu, ..Zeszyty Prasoznawcze" 1976 z. 2, s. 21-32: E. Chudziński, Gemezd icu'olucja gatunk"l, [w: Dziemuikarsturo isurutut medión', red. Z. Baucr. Z. Chudzoniskiego, Kraków 2000), s. 197-213; T. Klcin, Felictor.

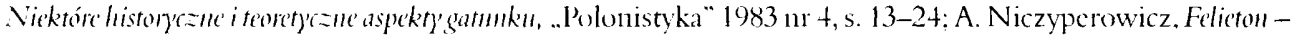

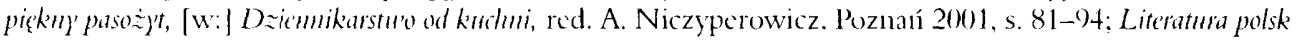

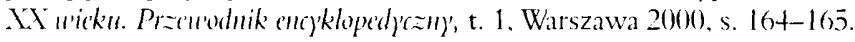

"M. Zionecki. Iademecum redakrora, Poznań 2001.

E. Skalski. Pracdmou'a do: Tademecomm reduktora, s. 5.

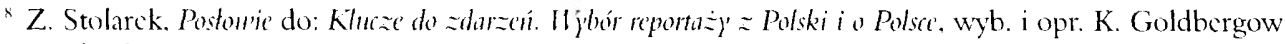
Z. Stolarek. Warszawa 1976, s. +29. 
sugeruje równiez tytul, skutecznie wabiący zarówno adeptów sztuki dziennikarskiej, jak i dziennikarzy praktyków. Sprytne skrócenie tytułu cyklu prasowych pierwowzorów", motywowane z pewnością ekonomiką słowa, opatrzenie tekstów przedmową uznanego autorytetu językoznawczego, prof. Jerzego Bralczyka, skutecznie ugruntowuje w odbiorcy przekonanie o obcowaniu z lekturą poważną i wpisuje książkę w szeroki kontekst publikacji podręcznikowych bądź poradnikowych. Że sztuka poradnicza to temat dla felietonı niezwykle wdzięczny, udowodnit przed wielu laty Karakuliambrow wirtuozerskim cyklu Estctyka $i$ źcic prakt)'zne, nota bene nie pominiętym $\mathrm{w}$ ostatnio wydancj retrospektywnej antologii felietonistyki w opracowaniu Andrzeja Możdzonka"'.

Tak więc już w sferze tytularnej Bereś i Skoczylas konstytuują kouwencję poradnika bądź podręcznika, by następnie podważyć ją i skompronitować. Bowiem Dziemnikarz doskonaty' to de facto doskonały antypodręcznik. To picrwsza prowokacja.

Pozornie wszystko wskazıje na zachowanie rudymentarnych elementów przyjętej konwencji. Niczym klasyczny poradnik Adama Stodowego, lub kompendium dla początkujących chiromantów czy adeptów sztuki koronczarskiej, każdy wykład ma układ dychotomiczny. Składają się nań: tekst główny (odpowiednik materiału teoretycznego) oraz zamieszczone poniżej przykłady językowe (niekiedy w sferze tytularnej odwołujące się do klasycznych ćwiczeń dla uczniów szkół podstawowych) ". Tyle, że 1 „nadwornych trefnisiów “Gazety Wyborczej”" "', jak określił autorów w dzienniku „Życie” Piotr Semka, teoretyczne podstawy warsztatu, miast ujęte zostać w karby zdyscyplinowanego akademickiego dyskursu, wyrażone są w formule frywolnego felietonu, a przykłady językowe opatrzone są niejednokrotnie niezwykle kąśliwym komentarzem. Oto więc prowokacja drugga.

Kolejnym dowodem na zakwestionowanie konwencji podręcznikowo-poradnikowej jest zaprzeczenie statusu autorytetu autorskiego. Jeśli przyjąć za Adamem Ropa ${ }^{13}$, że felieton ma strukturę hierarchiczną, to na jej szczycie znajdıje się figura narratora. To on wypehnia tekst swoją osobowością, emocjonalnością i światopoglądem. W kreacji narratora tekstów Beresia i Skoczylasa nie ma nic z mentorstwa i powagi natrętnej dydaktyki, której obecność nie powinma dziwić w konwencji kompendium. Wprawdzie podmiot mówiący informuje, że chce przyjać rolę .pani od polskiego" " ", a nawet manifestacyjnie rozpoczyna listę dziennikarskich blędów od wlasnych „.wpadek”, to jednak w odbiorcy szybko ugruntowuje się przekonanie, że mamy oto do czynienia jedynie z finezyjną przebieranką, ,felietonowym perskim okiem". Bowiem wpisany w tekst homo felictonicus nieustamnie kwestionuje swoje kompetencje. Podważa swoją wiarygodność autorytetu w sferze zdobytego wykształcenia, predyspozy-

\footnotetext{
${ }^{4} \mathrm{~W}$ miesiçczniku ,Press" interesujący nas cykl felictomów opatrzony był tytulem Jak zostać dzicmmikarze'm do-

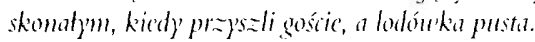

"Zob. Mistrzonic felietom, wyb. i opr. A. Możdzonck. Warszawa 1090.

"Zob. zestawy Gramatyka ma wesoto 1: Gramatyka ma ursoto 2.

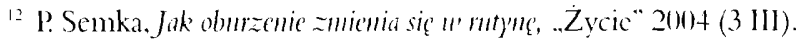

13 A. Ropa. op. cit.

it W. Bereś. I. Skoczylas, DEicumikar doskonaty, s. t9.
} 
cji dziennikarskich i inteligencji. Autorzy, nie chroniąc się pod pseudonimani I Iamiltonów, Pustelników czy Bywalców, z premedytacją „doprawiaja gębę” nie tylko swoim adwersarzom, ale i sobie samym.

...z czytania i pisania jesteśmy jak Maciej Boryna ${ }^{15}$;

...niżej podpisani we dwóch syntetyzują jednego półgłówka ${ }^{16}$;

Z języków obcych znamy tylko polski, ale i to nie za bardzo. Piszemy krótkimi zdaniami, bo zamiast uczyć się zdań złożonych, strzelaliśmy z procy do wróbelków. Gdy chcemy się wysłowić wykwintnie („Bardzo smaczna ta wiśniowa degrengolada, sama pani smażyła?"), to biorą nas za hydraulików, którzy mieli naprawić kran.

Po wtóre, narrator prowokuje eksplikacją nie nazbyt wyszukanych upodobań i manifestacją braku tak pożądanych w środowisku koneksji i kontaktów.

...z salonów znamy tylko salon masażu, salon do gry w bingo i salon pralniczy, gdzie plany na kolanach i lokciach czyszczą nam gratis ${ }^{17}$;

Skoczylas (...) wprawdzic nie ma matury, ale zna za to dużo lokalnej mlodzieży i jeszcze więcej mlodzieży lokalowej ${ }^{18}$;

Wzorem elegancji byl dla nas miastowy fryzjer. Wlosy mial pięknie ułożone brylantyną, zabójczy uśmiech, a przede wszystkim wykwintną mowę: - W tej fryzurze jest pani bynajmuiej do twarzy - mówił do klientki i miał zagwarantowany hojny napiwek. To dzięki niemu many na telewizorze sztuczne kwiatki, w kuchni makatkę „Dobrze nam smakuje, jak żoneczka gotuje”, a na ścianie w stołowym miejsce pod obraz. Pan Włodek obiecal nam coś ekstra: ,.Słoneczniki" albo coś z tych pikasów".

Poetyka groteskowego przerysowania okazıje siç pomocna również w opisach autorskich fizjonomii. Warto wspomnieć, że efekt karykaturalny potęgują rysunki Andrzeja Zaręby, które na okladce wpisują niechlujne sylwetki autorów raz w przaśny krajobraz wiejski, raz osadzająje w „rozpędzonej lokomotywie przemian”. Przywolajmy więc jeszcze raz atrybuty narratora: nieogolona twarz, tępe spojrzenie, intelektualne lenistwo, przerost „zainteresowai monopolowych", życiowe nicudacznictwo, programowy konformizm, głupkowata poczci. wość etc. Nie da się ukryć, że felietonowa maska, jaką przywdziewają dla potrzeb swojego cyk. lu autorzy, daleko odbiega od kostiumu salonowca - Passenta, erudyty — Słonimskiego cz

Ibidem. s. 64.

in Ibidem.

17bidem. s. 127.

"Ibidem. s. 75.

${ }^{14}$ Ihide'm, s. 167. 
Zanussiego, limika znad Wisty - Ryszarda Marka Gronskiego, omnibusa w sferze wiedzy o mediach anglosaskich - Ziomeckiego. Blizej jej do pozornie autodestrukcyjnej i autokompromitującej maski obrazoburcy Urbana ${ }^{211}$. Ale funkcjonalizacja kreacji podmiotu mówiąccgo w felietonach redaktora tygodnika "Nie” sprowadza się do odbierania broni polemistom, w Dziemnikarzu doskonaty'm zaś służy zjednaniu sympatii odbiorcy. I nawet jeśli przyjąć, że ta kreacja podmiotu mówiącego jest porte parole autorów, to rysunki Zaręby przekonuja, że poglądy narratora mają się tak do przekonań autorów, jak karykatury do zdjęć legitymacyjnych. Sprytnie podtrzymując przekonanie o wyobcowaniu gatunku felietonowego z socjalnego millien, nakładając nań narratorską postawę alienacji wobec środowiska zawodowego, kreując się na ćwierćinteligentów, nierozgarniętych i niedonczonych dziennikarzy, wspólczesnych Sanczo Pansów, autorzy ośmielają się nie tylko zdradzać innym arkana swojego rzemiosła, ale i pouczać. To prowokacja trzecia.

Pokusa dydaktyczna od zawsze przynależna byla gatınkowi felietonowenu, którego koneksje z poetyką kazania są aż nadto oczywiste ${ }^{21}$. Z punktu widzenia pragmatyki gatunku dysfunkcjonalne (a inudne zapewne) byłoby korzystanic z arsenałı wartości wzorcowych. Toteż idealny wzorzec metra z Sèvres pod Paryżem Bereś i Skoczylas zastępują kiepskąjego repliką, zapewne w słusznym skądinąd przekonaniu, że uczyć należy się na błędach. Ale przewrotność tej metody ma jeszcze inne implikacje. Oto dydaktyka i metodologia rodem z praktycznego kompendium odrzucone zostają na rzecz antydydaktyki i antymetodologii. A więc znowu poetyka wzorowego antypodręcznika. Oto więc prowukacja czwarta.

Realizuje się ona na dwóch co najmniej poziomach: w sferze merytorycznej i leksykalno-stylistycznej. Zacznijmy od tej pierwszej. Jak na poradnik przystało, napotykamy tu na catą gamę fachowych porad. Imperatyw pouczamia przyjumijemy wprzódy z calym dobrodziejstwem inwentarza, by skonstatować nagle iście diaboliczną, palimpsestową przewrotność metody. Tak jest w przypadku przekornej aprobaty dla ekshibicjonistycznego eksponowania osoby moderatora telewizyjnej debaty czy dziennikarza w sytuacji wywiadu, w przypadku rozgrzeszenia z grzechu plagiatu, aplauzu dla języka nazbyt wyszukanego, pretensjonalnego czy też skrajnie ubogiego, apologezy użyteczności wyrazów anglojęzycznych i lacińskich:

Podstawowa zasada dziennikarska: nie wolno używać prostego języka, bo publika zdemaskuje cię jako nieuka? ${ }^{2 ?}$

Po czym przeciętny widz pozna, że jesteś mądry? Po tym, że używasz słów, których nikt, poza spójnikami i przyimkami, nie rozumie. Ideałem jest, gdy myśli, ze to jest język zagraniczny ${ }^{23}$;

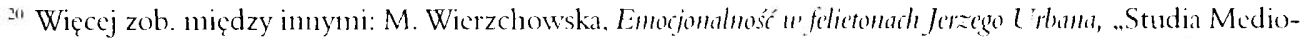

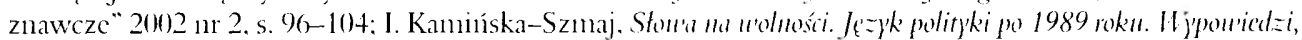
dourip polityceny, ston'nik imerkty', Wroclaw 2001, s. 92-112.

"2. Stasiński, op. cit., s. 7-853.

2. W. Bereś, J. Skoczylas, Dzicnnikurz doskonat)', s. 118.

23 Ibidem. s. 18.
} 
Taki profesor Geremek zna $180(0)()$ słów, niektóre w kilku językach. Ale to są szkodliwe miazmaty, które zabijają wrodzoną wewnętrzną harmonię i zdolność do życia w zgodzie z naturą ${ }^{2+}$;

Czy nie jest błędem wysyłanic kradzionych tekstów do tak poczytnego dziennika? Nie jest blędem ${ }^{25}$.

A dodać do tego należy manifestacyjne gloryfikowanie przeciętności, niewinne igraszki z deskrypcją dziennikarstwa sponsorowanego, cyniczny liberalizm dla błędów języka sportowych sprawozdań i komentarzy, czy wreszcie — podawanie w nawiasie nieprawidłowej wymowy obcojęzycznych słów. Pragmatykę tej metody najpełniej ilustruje „przepis na felieton" "26, w którym - jak na podręcznik przystało - wypunktowane skrupulatnie zasady realizacji gatunku ilustrowane są przykładami doskonale wręcz łamiącymi wszystkie wymienione prawidla. Jest to więc perswazja wyrażona implicite: przez kontekst i oczywisty kontrast. W tym whaśnie sensie felietony Beresia i Skoczylasa są ową „rękawiczką rzuconą w twarz" ${ }^{27}$, jak obrazowo pisal o konstytutywnych elementach gatunku Andrzej Niczyperowicz.

Jeśli w części, którą nazwaliśmy merytoryczną, obserwowaliśmy zabieg konstytuowania i aprobowania poglądów z gruntu falszywych, to w części leksykalno-stylistycznej mamy do czynienia z praktyczną realizacją owych zasad w tworzywie językowym. Jeśli przyjąć, że media

...odwierciedlają (...) aktualny stan języka ogólnego, rejestrują go, (...) wpływają na jego rozwój, popierając jedne występujące w nich tendencje, nie uwzględniając zaś innych, ksztaltıjąc mody językowe, a tym samym propagując okréślony wzorzec języka ${ }^{28}$,

to felietony Beresia i Skoczylasa są krzywym lustrem, koślawym sejsmografem, rejestrującym i zniekształcającym rozmaite wzorce obecności języka w mediach.

Zebrane w oddzielnym tomie felietony ukazują swą fabularną spójność. De facto jest tc rozpisana na segmenty epopeja drogi zawodowej dziennikarza, który próbuje swych sił raz w dziennikarstwie informacyjnym, raz w sztuce komentarza, romansuje $z$ TV i radiem, zmienia niwy zainteresowań ze sportowych na polityczne etc. Tym samym w toku lektury konsty. tuuje się obraz urozmaiconego krajobrazu polskich mediów. I to właśnie jest material paso. żytniczy felietonistyki duetu Bereś \& Skoczylas, oto jego żywioł pretekstowy. Narrator anek. tuje na swój użytek elementy języka obecnego w mediach i z tego tworzywa buduje swoje ma teriały. Jest to więc ,język cudzy", wobec którego narrator dystansuje się wprawdzie ostenta cyjnie, ale jednocześnie na kalkę owego podglądanego języka nakłada kliszę wlasnego war sztatu leksykahno-stylistycznego — jak się okazuje — równie ułonnego. Bowiem ,języ

- Ibidem, s. 31 .

25 Ibidem, s. 29.

2t Zob. rozdzial Lutnia po Passencie (Krzysztof Zamussi), s. 121-123.

27 A. Niczyperowicz, op. cit., s. 88.

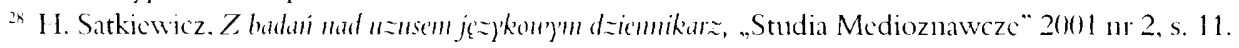


whasny" narratora jest konglomeratem blędów i potknięć, które z taką konsekwencją wy tykają mediom językoznawcze autorytety. Tym sanym tworzywo językowe staje się materią groteskowego przerysowania; ułomności języka nie są incydentalną „wpadką”, lecz konstytutywnym elementem wypowiedzi, obowiązująca manierą. Ów metajęzyk jest w pragmatyce interesujących nas felietonów elementem perswazji. Funkcjonalizacja metody jest oczywista: kompromitacja języka, destrukcja jeggo sensı, wskazanie na groźbę zachwiania podstawowych funkcji języka w mediach: komunikatywnej, ekspresywnej, impresywnej.

Przyjmując, iź badanie języka felietonistyki Beresia i Skoczylasa to zadanie skierowane do językoznawców, spróbujmy przyjrzeć się jedynie wybranym elementom tego tworzywa. W zakresie poprawności leksykahno-semantycznej autorzy szczególnie upodobali sobie błędy pleonazmów i tautologie, nieudolności konstrukcji wyrażeń peryfrastycznych i metaforycznych, bezrefleksyjne czerpanie z zasobów języka środowiskowego, grzechy nadużywania szablonu leksykalnego, zachwianie zasad łączliwości wyrazów (zwlaszcza w lączliwości idiomatycznej), nieuzasadniony aplauz dla leksyki obcego pochodzenia (głównie terminów anglojęzycznych i wyrazów lacińskich - efekt karykaturalny potęguje fakt, że te pierwsze w podane są często w transkrypcji fonetycznej). A do tego dorzucić należy między imnymi błędy fleksyjne, manierę anektowania na grunt prasy elementów nowomowy i stylu kancelaryjnego (kuriozalna zasada poprzedzania imienia nazwiskiem), hiperpoprawność językową.

Wyliczenie wszystkich „smaczków” stylistyki analizowanych felietonów wykraczatoby zdecydowanie poza ramy tego artykulu. W tym miejscu poprzestańmy na kilku zaledwie przykladach.

Nie czas wylewać róż, gdy idą żniwai ${ }^{29}$;

Tertium non pecunia det ${ }^{311}$ :

Na szczęście Tomasz Raczek znalazł uniwersalne placebo między tą Scyllą a Penatą

Sklepowa mówi „chlep” i ,jedwap”, na co Marek Markiewicz nigdy by sobie nie pozwolił. Jak powiedział ,ulg”, to usłyszeliśnny nie tylko dźwięczne ,g”, ale na dokładkę jeszcze ze trzy „y" ${ }^{\text {3? }}$;

Przepraszam, że absorbuję, ale rozmawiany o parsprototo, a tu czekają imponderabilia $^{33}$.

Trzeba przyznać, że autorzy Dzicmmikarza doskonatego z prawdziwą wirtuozerią posługuja się slowem. I jeśli powtórzyć za Passentem maksymę:

29. Wereś. J. Skoczylas, Dzicunikarz doskonduty', s. 75

31) Ibidem, s. s. 93.

${ }^{31}$ Ibidem, s. 129.

32 llbidem, s. 167-168.

$33 \mathrm{Ibidcm}, \mathrm{s} .175$. 
Wszystko może miéć wdzięk, ale felieton - niestety - musi ${ }^{34}$,

to śmiało odnieść ją można do realizacji spółki Bereś \& Skoczylas. Język tych felietonów, nie wyzbywając się swojego waloru jako nośnika informacji, pełni równiez funkcje autoteliczne. Parodiując język obecny w mediach, autorzy prowokują: intelektualnie, poznawczo i estetycznie. Poetyka pastiszu i groteski - ulubiona broń felietonistów - także i w tym wypadku okazıje powab i skuteczność. Bereś i Skoczylas, w tworzywie językowym oscylıjąc między swojską przaśnością a wyabstrahowanym z uzusu językowego wykwintem, chłoszczą intelektualnie każdą skrajność. I jeśli biorą dosłownie przykazania Walerego Pisarka: „trzeba pisać tak, jak mówisz” "35 , to zaraz uciekają w stronę stylu „napuszonego” - pehnego przesadnej ornamentyki lub skażonego nudą kancelaryjnych referatów. Z nieskrywaną satysfakcją eksplorują żargon marksistowskiej erystyki, szablon stylistyki rewanżystowskiej i elementy nowomowy. Mylne byłobyjednak przekonanie, że Bereś i Skoczylas wznosząlarum nad katastrofalnym zachwaszczeniem języka obecnego w polskich mediach. Takie aspiracje zostawiajajęzykoznawcom. Ubrani w narratorski kostium perweniuszy żumalistyki, tych, którzy dopiero przymierzają się do zdobycia kulturalnych i warsztatowych szlifów, konstruıją przerysowany, doprowadzony do absurdu obraz polskich mediów. Tworzywo językowe jest przy tym jedynie jedną z wielu ster, w którą uderzają autorzy.

Dezynwoltura, z jaką poruszają się autorzy w krajobrazie polskich mediów, jest oszałamiająca. Przywolania znanych tytułów prasowych, programów telewizyjnych, popularnych osób, nadają tekstom pikanterii i potęgują efekt prowokacji. Bo też autorzy uderzają także w VIP-ów. Śmieją się z narcystycznej postawy Krzysztofa Ibisza, egotyzmu Karola Małcużyńskiego, z nonszalancji Tomasza Raczki, z hiperintelektualizacji wypowiedzi Krzysztofa Zanussiego i hiperpoprawności postawy Marka Markiewicza. Drwina nie oszczędza ni okopów argumentacji lewicowej „,Trybuny”, ni skrajnych konstatacji pism prawicowych. Dostaje się nudzie wiejącej z anteny radiowej „Trójki” i pseudoawangardowym koncepcjom telewizyjnych „Wiadomości”. W felietonach pehno jest rozmaitych smaczków, które z latwościs rozszyfruja nawet nie nader pilni obserwatorzy sceny polskich mediów. Tak jest z torebk: Aleksandry Jakubowskiej, refleksjami nad sposobami „wyżywienia się” rządu, trawestacjam filmowych scen $z$ udziatem Bogusława Lindy etc. Farsowa, na prymarnym poziomie recepcj czytelniczej, konwencja wypowiedzi Beresia i Skoczylasa ma jednak swoje drugie dno. Por sarkazmem, kpiną i ironią kryją się sądy tyleż przewrotne, co dające do myślenia. Przykładen niech stuzą wariacje na temat zmanych tytulów prasowych: „Gazeta Wybrana”, dziennil „Rzeczpański”, tygodnik „Pokrętıie”, skindalizujący tygodnik „Jak Najbardziej Tak!”, „Wy życie”, . Tygodnik Samolubność, „Wasz Nocnik"3". Ze swadą autorzy anektują na grun swoich wypowiedzi elementy argumentacji pism wszystkich opcji politycznych: ośnieszają

\footnotetext{
${ }^{34}$ Cyt. za. P. Stasinski. op. cit., s. 133.

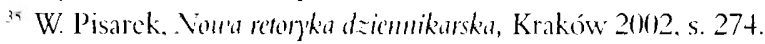

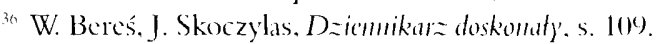


je, śmiało eskalując najbardziej radykalne ich tony, demaskując ich argumentacyjną niekoherencje ${ }^{37}$.

Te felietony prowokują na poziomic tréści i doboru środków językowych. Niggdy jednak nie przekraczają granic dobrego smaku. Nie ma tu agresji i wulgarności, a wpisane w tekst inwektywy bardziej śmieszą niż obrażają. A więc szyderstwo i inteligentna drwina bystrego Satyra miast furii i bezpardonowej napaści czy nudnego mentorstwa poważnych kompendiów. W niezobowiązującej konwencji felietonu autorom udało się ukazać rolę mediów w systemie zależności gospodarki rynkowej, biznesu i organizacji czasu wolnego dla milionów obywateli naszego spoleczeństwa. Polimorficzność krajobrazu polskich mediów cieszy i budzi obawy. Bereś i Skoczylas wiedzą, że nieustannie toczy się tu walka Karnawału z Postem, I lyde Parku z British Library. I choć walka to muiej intensywna niż w wysoce rozwiniętych technologicznie (i demokratycznie) spoleczeństwach zachodnich, to walkę tę traktują autorzy z należytą jej powaga.

...świat mediów jest taki jak dzisiejsze spoleczeństwa, jak my sami. (...) Dlatego tak ważne jest nie tyle nieustanne narzekanie na media, ile próba opisania ich i zrozumienia ${ }^{38}$,

pisał w Czu'artej utadzy' Witold Bereś. Wydaje się, ze Dziennikarz doskonaty to kolejna próba zmierzenia się z tematem. Niby nie na serio, a jednak... Bereś i Skoczylas udowadniają, że wypracowywanie strategii dziennikarstwa obywatelskiego, rzeczowego, mądrego, obiektywnego i etycznego, może odbywać się nawet na gruncie tak chwiejnyın jak felietonowy. A dla młodych adeptów rzemiosła potrawa to tyleż lekkostrawna, co smakowita i poznawczo pożądana. To inteligentne, choć deklaratywnie prowokacyjne, kompendium warsztatu dzienuikarskiego. Wszak juz hrabia Fredro pisał:

Nie umieć - nie ma grzechu. Ale wielki błąd: udawać, że się umie, czego się nie amie.

Tego między innymi uczy Dziennikarz doskonaty.

\footnotetext{
${ }^{77}$ Np. refleksje o „Naszym Dzicmniku” poprzedzają nastçpującym interhudium: ..Graham (irecn. znany kosmopolita, który nic zachorowal na AIIDS tỵlko dlatego, ż mmarl, zanim Żydzi wymyślili tę zaraz̨̧. ośmiclił sį̨ sowiedzié, ...". W. Bercś, J. Skoczylas. Dziemmikarz doskomaly', s. 79.

${ }^{i s}$ W. Bereś, Call'arta utadza, s. 19.
} 